\title{
Does an Internship Have Value for Political Science Graduate Students?
}

\section{Susan E. Baer, Ph.D. ${ }^{1}$}

\section{Introduction}

The discussion regarding political science internships often concentrates on undergraduate internships (Berg 2014; Donavan 2011; Van Vechten, Gentry, and Berg 2021), and the literature about internships for political science graduate students is scarce. Nonetheless, political science graduate students may also have the opportunity to complete an internship, depending on their university and department (Marando and Melchior 1997). A political science graduate student needs to consider multiple factors when deciding whether to complete an internship. This chapter begins by describing several tensions related to internships for political science graduate students, including issues of transferable skills, paid versus unpaid internships, and the need for a signed memorandum of agreement.

\section{Tensions Related to Internships}

Transferable or generic skills are professional skills applicable outside the university (Bos et al. 2017; Craswell 2007; Gilbert et al. 2004). It may seem obvious that graduate students in vocational fields such as medicine need to develop transferable skills, but one tension related to political science graduate students completing internships involves the question of whether they also need to cultivate transferable skills during their program of study. Examples of

\footnotetext{
${ }^{1}$ Online Lecturer, School of Public Affairs and Administration, The University of Kansas; and Contributing Faculty Member, School of Public Policy and Administration, Walden University
} 
transferable skills that political science graduate students may develop include the ability to work in teams, communicate effectively with nonacademic public audiences and policymakers (Gilbert et al. 2004), and use new software, among others.

According to APSA (2019), the percentage of nonacademic placements among persons entering the job market with a Ph.D. in political science has increased over the past eight years. In 2017-2018, approximately 11\% of those earning a Ph.D. in political science accepted a nonacademic placement. Given this trend, it becomes increasingly essential for political science graduate students to build transferable skills, which an internship may help to advance.

Even if a person earning a Ph.D. in political science accepts an academic appointment, possessing transferable skills such as the ability to communicate effectively with nonacademic audiences proves necessary given the teaching, research, and service expectations in academia. As an example, in a previous academic appointment I served as a co-principal investigator for a research study involving a pilot harm reduction program. One of my responsibilities included conducting a focus group of residents who lived in the neighborhood where the pilot program operated. I also helped to design a survey instrument about the program that was administered to community residents. These responsibilities required successful communication with nonacademic audiences, both verbally and in writing.

A second tension that applies to internships for political science graduate students involves the issue of whether an internship is paid or unpaid, and this chapter briefly highlights three criticisms about unpaid internships. First, internship providers may exploit students completing unpaid internships to get free labor (Perlin 2012; Perlin 2015; Smith 2006; Yamada 2021). Although the possibility for internship providers to exploit students in this way certainly exists, and all interns should ideally be decently paid, not all unpaid internships are necessarily 
exploitative or harmful. For example, in a survey study, Crain (2016) found that recent graduates rated unpaid internships as significant in helping to better understand academic coursework, while they did not rate paid internships as significant in this area. Second, unpaid internships receive criticism because they advantage those students who can afford to work for free (Yamada 2021), thus creating an issue of inequity for students who cannot afford to work without pay. Third, unpaid internships may present complex legal implications. As one example, people who do not receive compensation for their work may not be afforded legal protections from workplace harassment (Rothschild and Rothschild 2020). For a more detailed discussion of legal considerations surrounding unpaid internships, see Rothschild and Rothschild (2020) and Yamada (2021).

Whether the internship is paid or unpaid, it is not enough for political science graduate students to use an internship solely to enhance transferable skills. Political science internships must enable students to learn something significant about politics and political phenomena (Berg 2014; Hindmoor 2010), because the goal of a graduate political science internship should be to address students' substantive research interests in the field of political science.

Ensuring that internship responsibilities will be substantive involves legwork on the part of the political science graduate student and the instructor or faculty mentor responsible for internship placement. Specifically, students need to work with the instructor to attempt to ensure that internship responsibilities will provide an effective way to learn about some aspect of politics before they accept an internship placement. One way to accomplish this is by creating and signing a memorandum of agreement that delineates the responsibilities of all parties in the internship relationship (Marando and Melchior 1997). 


\section{Benefits of Completing an Internship as a Graduate Student}

When evaluating whether to complete an internship, political science graduate students must also consider the potential benefits of completing an internship. According to Marando and Melchior (1997), the benefits of internships for political science graduate students include the opportunity for students to evaluate political theory, develop research agendas, implement research skills, and broaden real-world experiences. This section briefly describes these benefits.

A beneficial nexus exists between internships and political theory (Marando and Melchior 1997; Moon and Schokman 2000). Specifically, an internship as a form of site-based experiential education offers a different vantage point for political science graduate students to critically engage with political theory learned in the classroom and deepen their understanding of political theory. The relationship appears reciprocal, because students may also use their existing knowledge about political theory to better understand substantive political phenomena examined during an internship.

Completing an internship may also help political science graduate students to develop a research agenda. According to Marando and Melchior (1997), observing the dynamics of political phenomena as an intern may provide valuable insight that assists political science graduate students in creating a research agenda that builds on earlier research. Auerbach (2021) describes a more formal approach for undergraduate political science interns to develop their agenda, including required attendance of a research skills seminar. The more formal training offered by an internship may greatly assist graduate political science interns in developing their research.

In addition, completing an internship may enable graduate students to participate in applied research projects. These projects may positively impact society, and students may gain a sense of satisfaction by participating in them. Participating in applied research may also impart 
knowledge about how to create high quality research in a shorter period of time than generally occurs in a traditional academic setting (Bos et al. 2017; Krull et al. 2001).

Graduate students who complete an internship may also benefit by further improving and implementing their research skills (Bos et al. 2017; Marando and Melchior 1997). When completing internships, for example, political science graduate students may learn how to ask better research questions that will lead to more meaningful research results. Students may also have the opportunity to develop both qualitative and quantitative research skills. Additionally, internships may enhance political science students' knowledge about public policy if interns can effectively gather and use data related to the policymaking process (Moon and Schokman 2000). Graduate students who participate in internships may also learn new forms of research dissemination that reach a far wider audience than academia (Bos et al. 2017).

Internships may also benefit political science graduate students by broadening their realworld experiences. Broadened real-world experiences may subsequently help students to become better teachers (Marando and Melchior 1997). Another benefit of broadened experiences includes graduate students being able to network and collaborate with people working in their field of study (Krull et al. 2001). Networking opportunities may lead to an additional reference for the graduate student from outside academia, or to the student securing a future nonacademic position. In addition, an internship allows graduate students to see the relevance and significance of their work outside academia (Bos et al. 2017).

\section{Recommendations and Reflection}

If political science graduate students decide to pursue an internship, I strongly recommend they attempt to ensure that it is properly structured before accepting an internship placement. As discussed in this chapter, a student must work with the instructor or faculty 
mentor responsible for internship placement to confirm that internship responsibilities will be both substantive and provide an opportunity for the student to learn something significant about politics. To best accomplish this, all parties in the internship relationship, including the student, instructor, and internship provider, should sign a memorandum of agreement that outlines the general responsibilities of all parties before the student accepts an internship placement.

Based on my own experience completing an internship as a political science doctoral student, I regard internships for political science graduate students as beneficial. My two areas of specialization as a Ph.D. student in the government and politics department at the University of Maryland, College Park were urban policy and political theory. I was motivated to pursue an internship because I believed it would offer a real-world vantage point to learn about urban policy and politics, and could potentially inspire new research ideas in this subfield.

I worked with my internship faculty mentor, who was a professor in the government and politics department and supervised the department's graduate internship program, to identify an appropriate internship provider. When I was ABD in the Ph.D. program, I completed my internship at the Charles Village Community Benefits District, which is a special taxing district in Baltimore, Maryland. Created in 1995, this special taxing district provides supplemental sanitation and safety services within district boundaries in addition to services the City of Baltimore provides (Charles Village Community Benefits District 2021).

My internship experience at the Charles Village Community Benefits District met my expectations and produced benefits that Marando and Melchior (1997) outline. As a result of my internship, I began to develop a research agenda that extended beyond my doctoral dissertation and applied political theory to understand the political process involved in creating community benefits districts in US cities. The initial stage of the research agenda setting process was 
relatively informal and involved discussing my internship observations with my internship faculty mentor. At the time I started to develop this research agenda, I was not sure whether I would pursue an academic appointment or a nonacademic position after earning my Ph.D. During a brief stint working in a nonacademic position immediately following graduation, I decided to pursue a career in academia.

In terms of unexpected gains from my experience, I did not expect to have the opportunity to co-author two peer-reviewed journal articles with my internship faculty mentor as a result of the research agenda I began to develop during my internship. While most political science graduate students may not have the opportunity to collaborate on research projects with their internship faculty mentor, it is crucial for students to attempt to build a constructive working relationship with their faculty mentor. Intern mentoring is defined as "the interaction of a faculty sponsor with an intern in order to facilitate learning" (Berg 2021: 62). The internship faculty mentor's main responsibility is to help the graduate student intern learn political science, and both the student intern and faculty mentor need to be actively engaged in the mentoring process for effective learning to take place. This means that students should attend and actively participate in all classes or meetings with their internship faculty mentor, as well as successfully completing all assignments related to the internship.

I also did not anticipate that the research agenda I started during my graduate internship would have such a positive ripple effect on my academic career. I was awarded a postdoctoral appointment at Indiana University's Workshop in Political Theory and Policy Analysis due to my research proposal to examine the political process involved in creating the Charles Village Community Benefits District. During my postdoctoral appointment, I co-authored my first peerreviewed journal article, which examined the creation of the Charles Village Community 
Benefits District using polycentrism (Baer and Marando 2001). I subsequently accepted a tenuretrack assistant professor position at San Diego State University (SDSU) where I co-authored a peer-reviewed journal article that analyzed the creation of the Charles Village Community Benefits District using transaction resource theory (Baer and Feiock 2005). In addition to teaching, other research activities, and service to the university and community, the publications stemming from my internship experience made a positive contribution toward my successfully earning tenure and promotion to Associate Professor of Public Administration at SDSU, where I was previously employed.

\section{Conclusion}

This chapter described issues related to internships that political science graduate students should contemplate. The chapter discussed tensions related to internships as well as benefits of internships. Drawing on both the literature and my own internship experience as a political science doctoral student, I believe internships can have great value for political science

graduate students. I encourage graduate students to seriously consider completing an internship if their university and department offer this experiential learning opportunity. 


\section{References}

American Political Science Association (APSA). 2019. "2017-2018 APSA Graduate Placement Report." https://apsanet.org.

Auerbach, Arthur H. 2021. "Constructing a Research Internship Program to Promote Experiential Learning." In Political Science Internships: Towards Best Practices, eds. Renee B. Van Vechten, Bobbi Gentry, and John C. Berg, 71-78. Washington, DC: American Political Science Association.

Baer, Susan E., and Richard C. Feiock. 2005. "Private Governments in Urban Areas: Political Contracting and Collective Action." The American Review of Public Administration, 35(1), 42-56. https://doi.org/10.1177/0275074004271717.

Baer, Susan E., and Vincent L. Marando. 2001. "The Subdistricting of Cities: Applying the Polycentric Model." Urban Affairs Review, 36(5), 721-733. https://doi.org/10.1177/10780870122185064.

Berg, John C. 2014. "Two Threats to Political Science Internships: Press Attacks and Incorrect Student Assumptions." Paper presented at the American Political Science Association, Washington, DC.

Berg, John C. 2021. "Mentoring Interns." In Political Science Internships: Towards Best Practices, eds. Renee B. Van Vechten, Bobbi Gentry, and John C. Berg, 61-69. Washington, DC: American Political Science Association.

Bos, Daniel, Robin Finlay, Peter Hopkins, Jenny Lloyd, and Michael Richardson. 2017. "Reflections on the ESRC Internship Scheme for Postgraduates." Journal of Geography in Higher Education, 41(1), 106-118. http://dx.doi.org/10.1080/03098265.2016.1260099.

Charles Village Community Benefits District. 2021. Accessed November 10, 2021. https://www.charlesvillage.org/about.

Crain, Andrew. 2016. "Exploring the Implications of Unpaid Internships.” NACE Journal, 2631.

Craswell, Gail. 2007. "Deconstructing the Skills Training Debate in Doctoral Education." Higher Education Research \& Development, 26(4), 377-391. doi: 10.1080/07294360701658591.

Donavan, Janet L. 2011. "Designing an Intellectually Challenging Internship Program.” Paper presented at the annual meeting of the American Political Science Association, Seattle, WA, September 1, 2011. 
Gilbert, Rob, Jo Balatti, Phil Turner, and Hilary Whitehouse. 2004. "The Generic Skills Debate in Research Higher Degrees." Higher Education Research \& Development, 23(3), 375388. doi: 10.1080/0729436042000235454.

Hindmoor, Andrew. 2010. "Internships Within Political Science." Australian Journal of Political Science, 45(3), 483-490. doi: 10.1080/10361146.2010.499186.

Krull, Ira S., Hongji Liu, Kavita Mistry, and Sarah Kazmi. 2001. "Industrial Internships (Co-ops) in Graduate School - How, When, Why, and Where?" Analytical Letters, 34(1), 1-15. https://doi.org/10.1081/AL-100002700.

Marando, Vincent L., and Mary Beth Melchior. 1997. "On Site, Not Out of Mind: The Role of Experiential Learning in the Political Science Doctoral Program." PS: Political Science \& Politics, 30(4), 723-728. https://doi.org/10.2307/420400.

Moon, Jeremy, and Wykham Schokman. 2000. "Political Science Research Internships and Political Science Education.” Politics, 20(3), 169-175. https://doi.org/10.1111/14679256.00127.

Perlin, Ross. 2012. Intern Nation: How to Earn Nothing and Learn Little in the Brave New Economy. Verso.

Perlin, Ross. 2015. “Interns, Victimized Yet Again.” The New York Times, July 3.

Rothschild, Philip C., and Connor L. Rothschild. 2020. "The Unpaid Internship: Benefits, Drawbacks, and Legal Issues." Administrative Issues Journal: Connecting Education, Practice, and Research, 10(2), 1-17. doi: 10.5929/2020.10.2.1.

Smith, Sonia. 2006. "Biting the Hand That Doesn't Feed Me: Internships for College Credit Are a Scam.” Slate, June 8.

Http://www.slate.com/articles/news_and_politics/hey_wait_a_minute/2006/06/biting the hand that d oesnt feed_me.html.

Van Vechten, Renee B., Bobbi Gentry, and John C. Berg, eds. 2021. Political Science Internships: Towards Best Practices. Washington, DC: American Political Science Association.

Yamada, David C. 2021. "Major Legal Considerations Pertaining to Internships." In Political Science Internships: Towards Best Practices, eds. Renee B. Van Vechten, Bobbi Gentry, and John C. Berg, 31-42. Washington, DC: American Political Science Association. 